chief classes of literature preserved in it must be added here.

Of almost the first importance for us are the large official authentic annals which were drawn up under the personal supervision of the high officials of the king, from which we gain very full accounts of the military expeditions undertaken by Sargon II., Sennacherib, Esarhaddon, and Ashurbanipal, and of their building operations. Intimately connected with these were the letters, despatches and reports written chiefly by the king's officials in various parts of the country, who by this means kept him informed of the progress of events in the countries under their jurisdiction. This class of document is of peculiar interest, and being in many cases dated they often afford precise information about important matters.

Next in importance come the tablets which deal with chronography and chronology, and by means of the socalled "Eponym Canon" it is possible to fix with exactness the dates of events which took place from about B.C. 900 to B.C. 640 .

The business side of Assyrian life is represented by a considerable number of "contracts," which relate to all the principal matters concerning the transfer for payment of human beings, and of property of all kinds.

A very large class of tablets deals with astrology, and provides innumerable examples of omens of all kinds; these prove that the warlike Assyrian must have lived in a state of almost abject fear of the various spirits and demons with whom he peopled heaven and earth. Every event which happened was construed as a portent, and the Assyrian astrologer must have spent most of his time in tabulating forecasts. Diseases were cured by means of incantations and magical formulæ, for all diseases, both of mind and body, were believed to arise through the evil influences of the stars; such influences could be diverted, however, by the use of certain herbs, plants, stones, and portions of the bodies of animals. The ghost, the "evil foot" at the door, the evil dream, the bite of a snake, the sting of a scorpion, were all treated in much the same way, i.e. by magical means. Two great series of incantations have been identified, and the rubrics of some of the texts reveal a depth of superstition in the mind of the Assyrian which seems almost incredible. The burning of magical figures made of clay, bitumen, honey, flour, bronze, or wood during the recital of magical formulæ was, of course, common, and it is quite clear, from the documents of this class, that the Assyrians thoroughly earned their name of "magicians and sorcerers." Curiously enough, the Library included large numbers of prayers, many of which contain expressions of lofty spiritual ideas, but these show at the same time that the Assyrian religion never freed itself from the shackles of the basest superstition. Many religious texts describe and contain instructions for the performance of important rites and ceremonies, and most minute instructions concerning the offering up of sacrifices, the festivals of the gods, the dress of the priests, \&c.

The legendary lore of the Assyrians is of peculiar interest, for it has preserved the history of the Creation and the account of the Deluge, which were incorporated by the Jewish compilers of the Hebrew Bible in Babylon.

We have already spoken at some length of the syllabaries, sign-lists and vocabularies which Ashurbanipal had drawn up, with Sumerian renderings arranged interlinearly, and from a modern point of view these will probably be regarded as the most valuable section of his Library. Dr. Bezold's Catalogue represents a vast deal of time and patience and hard work, and he is to be congratulated on the completion of a long and laborious task. There is no doubt that it will stimulate many in the prosecution of their Assyrian studies, and that it will greatly facilitate the rejoining of fragments of tablets; it will also help an investigator of any given class of tablets to produce an edition of its texts, which may be regarded as final until the tablets which still lie buried under the palace ruins at Nineveh are brought home to Bloomsbury. The thanks of every student of Assyrian are due to the Trustees of the British Museum for the production of such a costly but useful Catalogue.

\section{NAVAL BOILERS}

THE interim report of the Admiralty Committee upon "Modern Types of Boilers for Naval Purposes," recently published, has caused much discussion ; but, up to the present, it appears to have satisfied nobody and not to help the Admiralty much to settle the grave question of the best boilers for the future in the Navy. It gives the views, which are not so mature as could be desired, of the mercantile marine engineers of which the committee was chiefly composed, the experience of whom, up to the date of the appointment of the committee, had evidently been limited to the discarded cylindrical boiler.

The committee were asked ( $\mathbf{r}$ ) whether they consider water-tube boilers more suitable than cylindrical boilers for naval purposes; (2) if so, whether the Belleville is the best type of water-tube boiler for H.M. Navy; and (3) for suggestions on the extent to which any particular type or types of boilers should be fitted in new vessels. The replies given in the report are that "a satisfactory type of water-tube boiler" would be more suitable than the cylindrical boiler; that the Belleville boiler is not the type of water-tube boiler best adapted to the requirements of H.M. Navy; that Belleville boilers be not fitted in any ships not yet ordered, nor in any ships recently ordered for which the work upon the boilers is not too far advanced; but that they be retained in all completed ships and in all ships under construction for which the work is so far advanced as to involve delay in completion if the boilers were to be altered. The committee state that they have had under consideration four types of large straight tube boilers which have been tried in war vessels, viz., the Babcock and Wilcox, the Niclausse, the Dürr, and the Yarrow large tube boiler; and they suggest that "if a type of water-tube boiler has to be decided on at once for use in the Navy," some or all of these be taken. They recommend that boilers of these types be made and experimented with at the earliest possible date; and they call attention to the practical objections that have been found to the construction and working of the Belleville boiler.

The committee make the important admission that when the Belleville boiler was introduced into the Navy they consider "there was justification for then regarding it as the most suitable type of water-tube boiler for the Navy."

The only naval engineer upon the committee concurred with the report except that he considered, although the Belleville boiler has certain undesirable features, "it is a good steam generator, which will give satisfactory results when it is kept in good order and worked with the required care and skill"; and he sees "no necessity for delaying the progress of ships which have been designed for Belleville boilers in order to substitute another type of boiler."

This report does not satisfy the parliamentary opponents of the Belleville boiler, who appear to object to water-tube boilers of all kinds, and to advocate a return to the cylindrical boiler. In spite of the great advance recently made in the designs of boilers of water-tube type, they argue that because early attempts to use water-tube boilers at sea were unsuccessful, it is hopeless to expect any gond results from those now available. These opinions are not endorsed by engineers of wider experience, especially by the designers of machinery for warships, who understand better the relative advantages and disadvantages

No. $164 \mathrm{I}$, voL. 63 ] 
of different types of boilers from the point of view of warship requirements.

The Admiralty do not get much guidance from the report, and we understand that they only intend to supersede the Belleville boilers by those of Babcock and Wilcox and of the Yarrow types in a few vessels recently ordered, for which the boilers have not yet been put in hand. They had previously arranged for one of the recent cruisers to be fitted with boilers of the Niclausse type. The experiments recommended by the committee will doubtless be carried out as quickly as possible, after which there may be sufficient data available for determining the policy of the future.

The committee's report is distinctly disappointing, and suggests that their experience and judgment were not sufficiently matured to give much value to an interim statement. They seem to have been impressed by the advantages of good water-tube boilers for naval purposes, and to have realised that an ideal water-tube boilerwhich, however, has not yet been approached in practice --would be much better for the Navy than the old cylindrical boiler. When they have to choose the best of the types that are available, they name four which they have had under consideration and recommend early experiments with then, and there they leave the matter. Meanwhile, the construction of battleships and their machinery must go on, and the Admiralty engineers are in the difficult position of having to decide upon the boilers for them. This task is not rendered easier for the Admiralty in carrying on the work of the Navy, nor is any one helped in forming an opinion upon the best policy for the future by the fact that the objections to the Belleville boiler which are pointed out by the committee apply, in a greater or less degree, to others that might be substituted for it. One thing that appears certain is that whatever the defects of watertube boilers may be, or may be thought to be, their advantages to a warship are sufficiently proved to make a return to cylindrical boilers in the fighting navies of the world extremely improbable.

\section{FORESTRY IN GREAT BRITAIN.}

$\mathrm{T}$ is probably known to most people that for the supply of our requirements in the matter of timber, as in that of foodstuffs, we depend largely upon imports from abroad. But it may be doubted if many beyond the comparatively few who have given special attention to the subject have realised the fact that the annual cost to the country of these imports amounts to somewhere about twenty-five millions of pounds. It has been often urged that it would be worth some trouble to prevent this large sum, or a portion of it, going out of the country, and it has been pointed out that a proper system of forest management would bring about this result. Of course, so long as the foreign supply is ample and the price of imported timber is less than that at which it is profitably produced at home, our markets will continue to absorb foreign produce as heretofore; but these conditions which have hitherto prevailed are, in the opinion of experts, not likely to continue. For some years past this and cognate questions have attracted considerable attention, as witness the writings of recent date noted below, all of which are deserving of careful perusal. The burden of all of them may be summed up in the phrase cited by a writer in the Times of March 17,1899 . "'Cotton,' it is said on the other side of the Atlantic,

1 "Forest Management, with Suggestions for the Economic Treatment of Woodlands in the British Isles" (Trans. Surveyors Inst., 1900); "Canadian Trade with Great Britain" (Contemp. Kez'jere, Jan. 1900); "British Forestry and its Prospect:" (7rans. Koy. Scot. Arbor. Soc. vol. xvi. part $n, x q u)$; " Deficient Production of Timber in the World" (Trans. Eng. Arbur. Soc., vol. iv. part $11 \mathrm{r}$, rgos); "Outlook for the World's Timber Supply." Report of a lecture by Dr. W. Schlich (Journal of the Society of Arts, ilarch 1 ).

No. 1641 , vo L. 63] 'was once called king ; but King Cotton is a lesser potentate than King Timber must soon become." In other words, the world's demand for timber is outrunning the supply under present methods, and an appreciation of timber values is therefore setting in which is likely to be permanent and progressive. Cheap timber is probably a thing of the past in this country. To some such a declaration will only appeal as the old cry of "wolf," and they may argue that any scarcity of timber will be balanced by the substitution for it, in many cases, of other suitable products; and such substitution has, no doubt, in the past taken place, as, for example, in shipbuilding. But it must be remembered that facility of transport has by now led to inroads into the world's timber capital in practically every timber-producing region, and the ruthless destruction of virgin forest without attempt at regeneration has brought us now within measurable distance of the end of the natural supply; and, further, in recent years the applications of timber to other purposes than those of construction, as, for example, in the manufacture of wood-pulp, have made it an efficient substitute for other products, and thus the demands for it have been multiplied, and may be yet increased. In these circumstances, then, not from any sentimental ideas connected with the growing of timber at home, but from the standpoint of business principles, the question of the growing of timber in Great Britain to an extent which shall in some measure make us less dependent upon foreign supply is one which has now assumed practical importance.

That wood can be profitably grown in Great Britain, even under the unscientific methods now in operation, has been amply proved; that under a system of scientific management crops of timber could be raised to yield a certain and adequate return upon capital is demonstrable. What lies at the bottom of the absence of such crops in this country is want of appreciation, from land-owners down to the working forester, of the right principles upon which they can be grown. There is, speaking generally, no practice of scientific forestry in (ireat Britain. Other immediate causes there are which have contributed more or less to the neglect of scientific forestry in Britain, for instance, tenure of land, the claims of sport - this probably one of the most influential factors-the rating of woods, and so forth. These are obstacles, and no doubt will remain so, in the way of tree-planting ; but assuredly were our landed proprietors, land-arents and foresters better instructed in the methods of growing timber and in the possibilities of remunerative crops, less would be heard of them as such. It is difficult to instil into those who have been brought up in other traditions the fact that trees which are to yield a crop of timber must be grown under rules as definite as those which govern the cultivation of ordinary agricultural crops, because the time which is required for the maturation of the crop and the securing of the final yield exceeds the lifetime of the individual. Yet it can only be when this fundamental fact has been realised that a supply of marketable home-grown timber will be available in Great Britain.

There are not, it is gratifying to note, wanting indications that already some proprietors, even the Government, are appreciating the necessity and the advantage of cultivating their woods upon rational lines. Working plans for the econonical management of woods have been prepared and adopted upon estates of the Earl of Selborne in Hampshire-of which an account will be found in the Transactions of the Royal Scottish Arboricultural Society already cited-of the Duke of Bedford at Woburn, of Mr. Munro Ferguson at Raith and Novar, and in the Forest of D)ean the Government has similarly arranged a working plan. These working plans, which are a novelty in the country, are worthy of study by those who own woodlands, for they indicate the method which ought to be followed upon every estate where it is desired to grow wood for profit. Hitherto proprietors who 